\title{
Local extinction of an important seed disperser does not modify the spatial distribution of the endemic palm Astrocaryum aculeatissimum (Schott) Burret (Arecaceae)
}

\author{
Rodrigo Zucaratto ${ }^{1 *}$ and Alexandra dos Santos Pires ${ }^{1}$
}

Received: January 12, 2015 Accepted: February 22, 2015

\begin{abstract}
Spatial pattern of the palm Astrocaryum aculeatissimum was investigated in an urban Atlantic Forest fragment (Tijuca National Park, Brazil) where its main seed disperser, the red-rumped agouti Dasyprocta leporina, is locally extinct. A $120 \times 130 \mathrm{~m}$ plot (1.56 ha) was established in which all A. aculeatissimum individuals were quantified, georeferenced, and classified by ontogenetic stages, namely, seedling, infant, juvenile, immature individual, and adult. Analyses were performed using Ripley's $K$ function. We recorded 376 individuals, most of which were in the juvenile stage ( $\mathrm{n}=$ 228). The spatial pattern was aggregated as observed for other palm species. Seedlings and infants were not associated with adults, whereas juveniles and immature individuals were observed closer to adults than expected. The distance between each seedling and the nearest adult ranged from 3 to $30 \mathrm{~m}$ (mean $\pm \mathrm{sd}=11.8 \pm 7.8$ ), which is similar to the agouti dispersal distances reported in other studies. Despite the importance of agoutis for the seedling recruitment of A. aculeatissimum, their short-term absence does not affect the spatial distribution of this palm in the studied area.
\end{abstract}

Keywords: Atlantic Forest, palm, recruitment distances, Ripley's $K$ function, spatial patterns

\section{Introduction}

Description of spatial patterns is a central focus in ecology, providing important information regarding the processes that structure plant populations (Barot et al. 1999; Costa \& Santos 2011). Many factors, either biotic or abiotic, influence distribution patterns of individuals in a population (Barot et al. 1999; Condit et al. 2000; Capretz et al. 2012). Among biotic factors, the processes related to seed dispersal and predation have been recognized as important determinants of tree spatial arrangement in the tropics (Janzen 1970; Connell 1971; Augspurger 1984; Forget et al. 1994; Seidler \& Plotkin 2006).

In tropical forests, most trees produce fruits dispersed by vertebrates (Howe \& Smallwood 1982; Howe 1984). Thus, the lack or low density of seed dispersers causes an accumulation of seeds beneath parent plants (Galetti et al. 2006; Wang et al. 2007; Kurten 2013). Such accumulation can reinforce density-dependent effects (Janzen 1970; Connell 1971), resulting in reduced seedling recruitment (Chapman \& Chapman 1995; Cordeiro \& Howe 2001; Wright 2003; Terborgh et al. 2008). In contrast, in fragmented sites, where seed predators are also absent or less abundant, recruitment increases near parent plants (Wright \& Duber
2001; Dracxler 2012). In both cases, there is a reduction in seedling recruitment distances, suggesting that the foraging behavior of seed dispersers may have a strong effect on plant spatial distributions (Jordano 2000). Several studies have reported that as a consequence of anthropogenic disturbance defaunation can affect the long-term spatial distribution of plant species (e.g., Wright et al. 2000; Silva \& Tabarelli 2001; Webber et al. 2010). However, even in areas where this process has more recently occurred (e.g., <40 years), changes in plant species spatial distributions may also follow (e.g., Almeida \& Galetti 2007; Cramer et al. 2007).

Among the plants that rely on animals for seed dispersal, palm trees (Arecaceae) are dominant in tropical forests (Henderson et al. 1995). For large-seeded species $(\geq 1.5 \mathrm{~cm}$, Tabarelli \& Peres 2002), such as those from the genus Astrocaryum, seed dispersal is dependent on medium and large-sized mammals (Zona \& Henderson 1989; Zona 2006; Andreazzi et al. 2009). Among these animals, agoutis (Dasyprocta spp.) have been recognized as the most important dispersers (Smythe 1989; Pires \& Galetti 2012). Recent studies have demonstrated that in fragmented or defaunated forests, where agoutis are rare or have been absent for at least 40 years, Astrocaryum seedling recruitment was greatly reduced (Galetti et al. 2006; Donatti et

\footnotetext{
${ }^{1}$ Laboratório de Ecologia e Conservação de Florestas, Departamento de Ciências Ambientais, Instituto de Florestas, Universidade Federal Rural do Rio de Janeiro, BR 465, Km 07, 23890-000, Seropédica, RJ, Brazil

"Corresponding author: rzucarattobio@gmail.com
} 
al. 2009; Jorge \& Howe 2009) and more aggregated around parent trees (Dracxler 2012). However, the consequences of the absence of these animals for palm spatial patterns remains poorly understood.

Herein, we investigated the spatial distribution of Astrocaryum aculeatissimum in a large urban Atlantic Forest fragment, where its main seed disperser, the red-rumped agouti Dasyprocta leporina, is locally extinct. More specifically, we investigated the spatial pattern of the population, the spatial relationship between individuals of different ages, and the distance between seedlings and adults. The following hypotheses were tested: (i) the population distribution is aggregated, (ii) seedlings and infants are spatially associated with reproductive adults, and (iii) distances between seedlings and adults should be lower than the dispersal distances commonly performed by agoutis.

\section{Material and methods}

\section{Studied species}

Astrocaryum aculeatissimum (Schott) Burret (brejaúva palm) is endemic to the Brazilian Atlantic Forest, occurring from Bahia to Santa Catarina (Henderson et al. 1995). Stems are solitary or aggregated and can reach $8 \mathrm{~m}$ in height. The fruits are spiny, ovoid, or pyriform, with a thin and fibrous mesocarp, and a hard endocarp (Lorenzi et al. 2004). Fruit length and diameter are $3.5-4.5$ and $3.0-3.5 \mathrm{~cm}$, respectively (Henderson et al. 1995). Fruiting is annual with a peak between December and March (Lorenzi et al. 2004). Fruit productivity is high, with $100-500$ fruits per stem (Pires 2006; Dracxler et al. 2011). Seed germination is slow, taking from 3 to 18 months (Lorenzi et al. 2004; Zucaratto 2013), with a high seedling establishment rate (ca. 87\%; Portela et al. 2010). Besides their large size, the absence of pulp further reduces the range of frugivorous vertebrates that consume A. aculeatissimum fruits. Small rodents (Trinomys spp.), squirrels (Guerlinguetus ingrami Thomas), and collared peccaries (Pecari tajacu L.) are reported consumers of these fruits (Andreazzi et al. 2009; Donatti et al. 2009; Pires \& Galetti 2012). Among invertebrates, bruchine and scolytine beetles are the most important seed predators (Dracxler et al. 2011). Agoutis (Dasyprocta spp.) have been identified as the main seed dispersers of this palm species (Donatti et al. 2009; Pires \& Galetti 2012).

\section{Study area}

The study was conducted in the Tijuca National Park (TNP), Rio de Janeiro, Brazil (22 $2^{\circ} 5^{\prime}-23^{\circ} 00^{\prime} \mathrm{S}$ and $43^{\circ} 11^{\prime}-$ $43^{\circ} 19^{\prime}$ W). With a total area of 3,593 ha, the Park is divided into four sectors: Floresta da Tijuca, Serra da Carioca, Pedra Bonita/Pedra da Gávea, and Pretos Forros/Covanca. This study was conducted only in the Floresta da Tijuca sector. The region has a tropical climate, with wet (September-April) and dry (May-August) seasons. Annual precipitation exceeds 2,000 $\mathrm{mm}$, and mean monthly temperatures vary between $18^{\circ} \mathrm{C}$ and $22^{\circ} \mathrm{C}$. Altitude varies between 80 and $1,020 \mathrm{~m}$. The vegetation is in an advanced stage of regeneration, resulting from human interventions that occurred between the $17^{\text {th }}$ and $19^{\text {th }}$ centuries (Drumond 1988; ICMBio 2008). Due to anthropogenic impacts, many animal and plant species have become locally extinct (ICMBio 2008). Dasyprocta leporina L. was considered rare in the area in the late 70 s when some individuals were released to reinforce population sizes (Coimbra-Filho \& Aldrighi 1971). However, these releases were made only in the Carioca sector and in different locations (Coimbra-Filho \& Aldrighi 1971; Coimbra-Filho et al. 1973). Despite this repopulation attempt, the low number of released individuals $(\mathrm{n}=25$; Coimbra-Filho et al. 1973) and the absence of monitoring suggests that restocking was unsuccessful. As reported by Cid et al. (2014) and indicated by interviews with former TNP employees, agoutis have not been sighted in the last 20 years, although these animals are easily sighted (Jorge \& Peres 2005). At the end of 2009, an agouti reintroduction program was initiated in the area (Cid et al. 2014) to restore ecological processes. However, as animal releases were only performed in a small area of the Floresta da Tijuca sector, most of the Park is still uninhabited by them, as shown by continuous camera-trapping and radio-tracking monitoring (Zucaratto 2013; Cid et al. 2014).

\section{Sampling}

Astrocaryum aculeatissimum individuals were sampled in a plot of $120 \times 130 \mathrm{~m}$ (1.56 ha) from June to August 2012 . The plot was demarcated in an area where agoutis had not yet established (Zucaratto 2013), the terrain slope was not exceptionally steep, and no trails crossed (22057'39.0" S$43^{\circ} 17^{\prime} 50.2^{\prime \prime} \mathrm{W}$ ). All $A$. aculeatissimum individuals in the plot were sampled, and their geographic coordinates were recorded with the aid of a GPS device (Garmin eTrex ${ }^{\circledR} \mathrm{H}$ ). Additionally, each individual was classified into one of the following ontogenetic stages (Portela \& Santos 2011): (1) seedling, individuals with bifid leaves; (2) infant, individuals with transitional leaves (between bifid and pinnate); (3) juvenile, individuals with pinnate leaves but no aerial stems; (4) immature, individuals with apparent stems but no sign of reproductive structures; and (5) adult, individuals with signs of previous reproductive events (presence of inflorescences or infructescences). When a palm clump was sampled, only the individual in the highest ontogenetic stage was recorded and considered in the analyses. This procedure was adopted to avoid an overestimation of aggregation degree, resulting from clonal growth (Portela 2008).

\section{Data analyses}

The analysis of spatial distribution was performed using Ripley's $K$ function (Ripley 1977). Ripley's $K$ function is a 
density probability function that permits a second-order analysis. It is based on second-order measures, i.e., the variance of all point-to-point distances (Ripley 1977; Haase 1995). Ripley's $K$ function is considered the most appropriate statistical tool for the analysis of spatial patterns (Haase 1995; Dixon 2002). The procedure comprises delimitating a circle of radius $s$ centered on each point and counting the number of neighbors within this circle (Haase 1995; Anjos et al. 1998). By varying the radius $s$, it is possible to determine the pattern at different distance scales. To facilitate the visualization of the results, the $K(s)$ function was transformed into an $L(s)$ function (Ripley 1979).

To analyze the spatial distribution of the species, we used the univariate $K$ function. Deviations were tested for complete spatial randomness (CSR) through 500 Monte Carlo simulations that generates maximum and minimum confidence intervals. Positive values of $L(s)$ indicate aggregation, and negative values indicate regularity. If the spatial pattern is completely random, the $L(s)$ function will appear as a line within confidence intervals. The relationship of dependence or independence between adults and other ontogenetic stages was analyzed using the bivariate $K$ function. In this case, deviations were tested for complete spatial independence (CSI). Maximum and minimum confidence intervals were also generated, and their interpretation was analogous to that of the univariate $K$ function. Positive values of $L(s)$ indicate association, and negative values indicate repulsion. To avoid inaccurate estimates, the radius used to calculate the $K$ function ranged from 1 to $60 \mathrm{~m}$ with a constant increment $(1 \mathrm{~m})$ up to the maximum scale of analysis, which corresponds to half of the smallest side of the plot (Ripley 1977). All analyses and their confidence intervals were generated using the SpPack software (Perry 2004).

The distances between each seedling and the nearest adult were considered the minimum dispersal distance and obtained using the geographic coordinates of each individual. The comparison with individual recruitment in the area where agoutis were reintroduced was not possible because the agouti population was not completely established when this study was conducted as well as the long germination time of Astrocaryum spp. (>13 months; Potvin et al. 2003). As an alternative analysis, we compared our results with the dispersal distances attributed to agoutis when dispersing A. aculeatissimum and other Astrocaryum seeds. All studies considered used comparable methods.

\section{Results}

We found 376 individuals of $A$. aculeatissimum in the sampled area. Individuals of all ontogenetic stages were found. Most sampled individuals belonged to the juvenile stage (c. $60 \%, \mathrm{n}=228$ ), followed by the immature stage (c. $18 \%, \mathrm{n}=67)$. Adults corresponded to $8 \%(\mathrm{n}=31)$ of all individuals registered, whereas infants and seedlings corresponded to $7 \%$ each $(n=25)$.
The overall population demonstrated an aggregated pattern, and CSR was rejected across all distance classes (Fig. 1). Given the spatial relationship between individuals of different ontogenetic stages and adults, an association was found only at advanced stages. Seedlings and infants revealed CSI from adults, although a trend to repulsion was observed at short distances ( $<2 \mathrm{~m}$; Fig. 2A-B). Juveniles and immature individuals were associated with adults, particularly in the greater distances analyzed (Fig. 2C-D).

The distance between each $A$. aculeatissimum seedling and the nearest adult ranged from 3 to $30 \mathrm{~m}$ (mean $\pm \mathrm{sd}=$ $11.8 \pm 7.8)$, and $72 \%$ of them were recruited in the immediate vicinity of parent palms (<15 m; Fig. 1A).

\section{Discussion}

At the analyzed scale, $A$. aculeatissimum individuals have an aggregated distribution, as observed of other palms (e.g., Silva \& Tabarelli 2001; Silvius \& Fragoso 2003; Almeida \& Galetti 2007). One explanation for the aggregated pattern usually observed among plants in the Arecaceae is seed dispersal limitation because the typical large size of their seeds limits the number of animal species that can carry them over long distances (Silvius \& Fragoso 2003).

Considering the spatial relationship between individuals of different ages, we did not find an association among individuals at earlier stages and adults as expected. The repulsion observed among seedlings and infants very close to adults $(<2 \mathrm{~m})$ can be explained by the high mortality of seeds accumulated immediately around parent trees. In these areas, predation by invertebrates is usually very intense (e.g., Galetti et al. 2006), limiting seedling recruitment. However, we did not observe predation of A. aculeatissimum seeds by bruchines in the park, and few endocarps (five of 41) had signs of damage by scolytines (Zucaratto 2013). In this case, the predation intensity could not have been distancedependent or may also have been substantially away from parent trees (Dracxler et al. 2011). Ultimately, invertebrate seed predation did not appear to be a factor that affected the association between individuals at earlier stages and adults.

The physical damage caused by the falling of vegetative structures is one factor that may explain the repulsion found among seedlings and infants very close to adults $(<2 \mathrm{~m})$; it has been considered a major cause of seedling mortality in the vicinity of arboreal palms (e.g., Peters et al. 2004). This was demonstrated by Silva and Tabarelli (2001) in a study performed on the palm Bactris acanthocarpa in a remnant of Atlantic Forest in northeast Brazil. They found that approximately $80 \%$ of seedling mortality occurred under the adult palm crowns $(<4 \mathrm{~m})$.

The survival of individuals farthest from parent trees may be one of the factors responsible for the spatial association between the more advanced ontogenetic stages and adults, especially at the higher distances analyzed. Additionally, soil characteristics and topography, which have been 

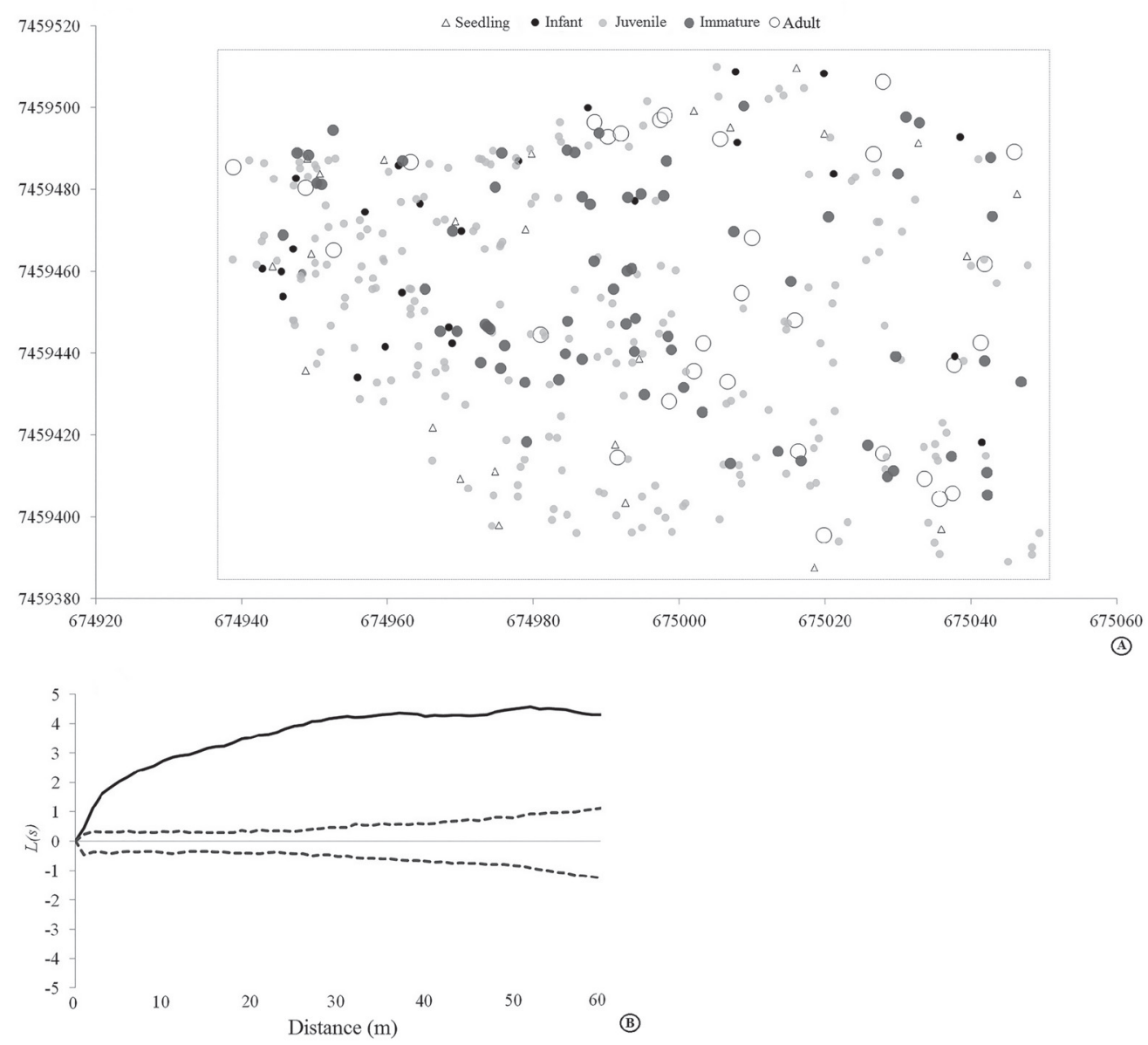

Figure 1. (A) Distribution map of the palm Astrocaryum aculeatissimum in Tijuca National Park, Rio de Janeiro, Brazil. The map is in UTM coordinates, and the dashed rectangle represents the sampled plot. (B) The adjustment for Ripley's $K$ function $L(s)$ univariate case. The dashed lines indicate the confidence envelops (99\%), within which the hypothesis of complete spatial randomness (CSR) is accepted.
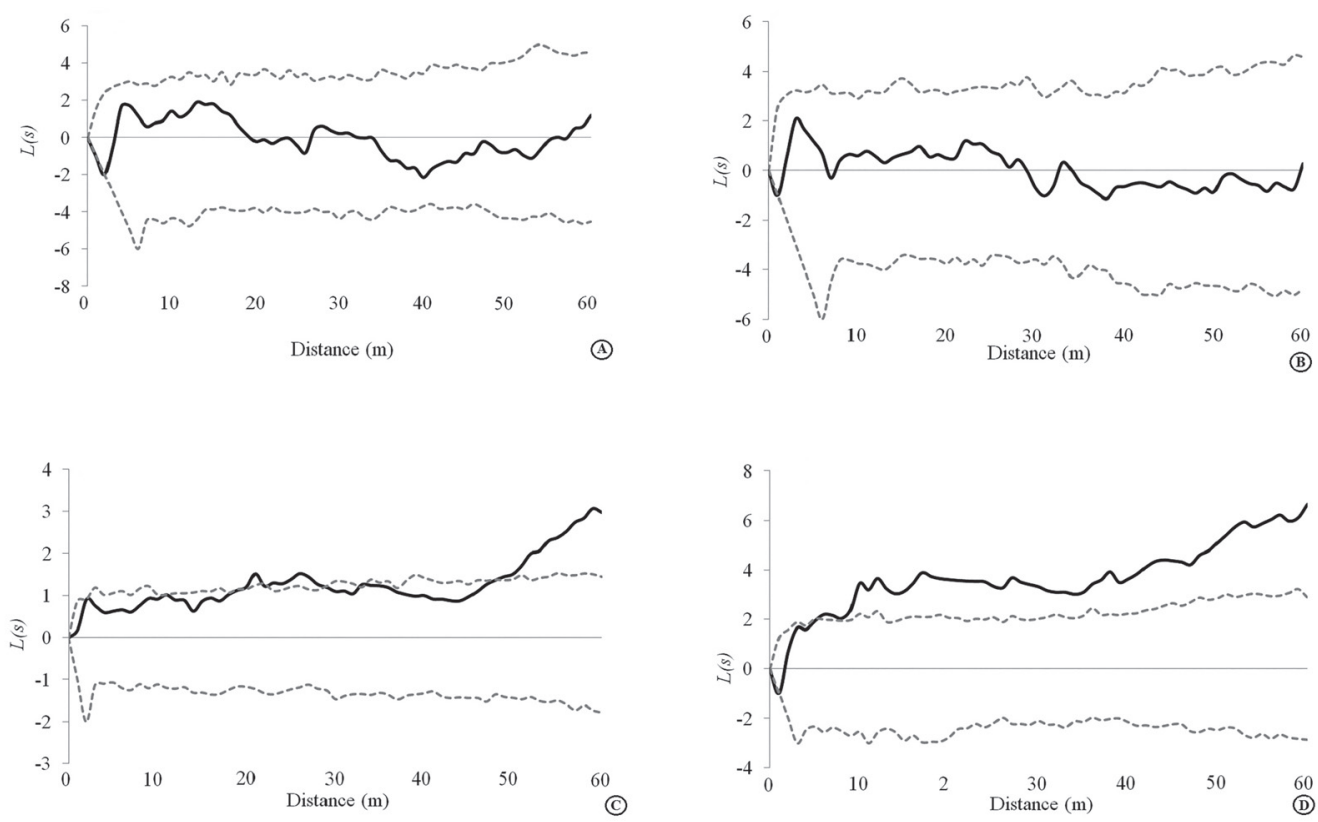

Figure 2. The adjustment for Ripley's K function $L(s)$ bivariate case calculated for (A) seedlings, (B) infants, (C) juveniles, and (D) immature individuals, all with adults. The dashed lines indicate the confidence envelops ( $99 \%)$, within which the hypothesis of complete spatial independence (CSI) is accepted. 
identified as determinants of the spatial distribution of the palms (Clark et al. 1995; Vormisto et al. 2004; Svenning et al. 2009), may also contribute to our result. This pattern occurs because surviving individuals are generally concentrated on resource-rich patches with suitable soil and topography. Thus, individuals in the advanced ontogenetic stages tend to remain in areas near other adults, which would be the areas with the best resource conditions. However, because of the high intraspecific competition in these patches, only a few individuals survive until the final stage (Barot et al. 1999), which may explain the more marked pattern of association between immature individuals and adults. Considering the importance of dispersers in this process, this may also have been influenced by the dispersal distances promoted by rodents (Svenning 2001).

As a previous study revealed that agoutis disperse $A$. aculeatissimum seeds over longer distances than spiny rats or squirrels (Donatti 2004), a shortening in distances between seedlings and adults in the absence of agoutis was expected. However, most of the seedlings were recruited at mean distances commonly reported in other studies involving Astrocaryum spp. and agoutis (Jorge \& Howe 2009, 6.4 m; Pires \& Galetti 2012, 6.8 m, Hirsch et al. 2012, 16.8 m; Kuprewicz 2013, 6.6 m). Given that these recruitment distances do not differ from those in places where agoutis are present, these dispersal distances may have been facilitated by other small rodents present in the area. Furthermore, in a study comparing A. aculeatissimum seed dispersal in areas with and without agoutis in TNP, dispersal distances via small rodents and agoutis were not observed to differ (Zucaratto 2013). Although small rodents are primarily seed predators, some of them act as effective dispersers by scatter hoarding seeds on favorable germination sites; thus, protecting them from other predators (e.g., Forget 1991; Hoch \& Alder 1997; Brewer \& Rejmáneck 1999).

As large-seeded palms $(\geq 1.5 \mathrm{~cm})$ usually have an aggregated spatial distribution and the seedling recruitment distances observed were similar to those performed by agoutis in other areas, the absence of these animals does not appear to have affected the spatial patterns of A. aculeatissimum. However, agoutis also have great influence on seedling recruitment rates for this palm (e.g., Galetti et al. 2006, Donatti et al. 2009). In the studied area, the A. aculeatissimum seedling-to-adult ratio was lower than that reported in large ( $>3,000 \mathrm{ha})$ Atlantic Forest remnants, and the population structure demonstrated a different pattern from a J-reverse curve (Zucaratto 2013). The observed pattern is characteristic of a population imbalance and can lead to a population decline if it persists (Hall \& Bawa 1993). Therefore, with the reintroduction of agoutis in the studied area, an increase in the abundance and density of seedlings is expected, with corresponding changes in the population structure. However, specific changes in the spatial patterns are not expected; because of the high complexity of animal-plant interactions, this cannot be predicted with certainty. Future increases in the abundance of agoutis could alter palm distributions through their caching behavior, including high seed pilferage and high rates of re-caching. In such cases, seeds can be carried into areas of low-adult density, and thus maintain a low background seed density, in which seeds have a lower probability of being stolen by competing rodents (Hirsch et al. 2012). If this occurs, palm spatial structure can be affected; future studies are necessary to determine the effects of agouti reintroduction on palm spatial structure.

\section{Acknowledgments}

We thank the Programa de Pós-Graduação em Ciências Ambientais e Florestais, where this work was developed, for logistical support; CAPES for the scholarship of the first author; the Fundação Grupo o Boticário de Proteção à Natureza and FAPERJ for funding; and the Parque Nacional da Tijuca staff, particularly Henrique L. T. Zaluar and Katyucha V. K. A. Silva, for all the support to the project. Ana Flora de Toledo e Mello and Daniel Cunha Passos provided valuable help during fieldwork. Yves Conjaud and Bernardo Araújo revised the English version of this manuscript. Mauro Galetti, Rita Portela, Fernando Silveira, and the anonymous reviewers provided valuable suggestions to previous versions of this work.

\section{References}

Almeida LB, Galetti M. 2007. Seed dispersal and spatial distribution of Attalea geraensis (Arecaceae) in two remnants of Cerrado in southeastern Brazil. Acta Oecologica 32: 180-187.

Andreazzi CS, Pires AS, Fernandez FAS. 2009. Mamíferos e palmeiras neotropicais: interações em paisagens fragmentadas. Oecologia Brasiliensis 13: 554-574.

Anjos A, Couto HTZ, Batista JRAA. 1998. Análise do efeito de um manejo em regime de rendimento sustentável sobre o padrão de distribuição espacial do Palmiteiro (Euterpe edulis Martius), utilizando a função K de Ripley. Revista Árvore 22: 215-225.

Augspurger C. 1984. Seedling survival of tropical tree species: interactions of dispersal distance, light-gaps and pathogens. Ecology 65: 1705-1712.

Barot S, Gignoux J, Menaut J. 1999. Demography of a savanna palm tree: predictions from comprehensive spatial pattern analyses. Ecology 80: 1987-2005.

Brewer SW, Rejmánek M. 1999. Small rodents as significant disperses of tree seeds in a Neotropical forest. Journal of Vegetation Science 10: 165-174.

Capretz RL, Batista JLF, Sotomayor JFM, Cunha CR, Nicoletti MF, Rodrigues RR. 2012. Padrão espacial de quatro formações florestais do estado de São Paulo, através da função K de Ripley. Ciência Florestal 22: 551-565.

Chapman CA, Chapman LJ. 1995. Survival without dispersers: seedling recruitment under parents. Conservation Biology 9: 675-678.

Cid B, Figueira L, Mello AFT, Pires AS, Fernandez FAS. 2014. Short-term success in the reintroduction of the red-humped agouti Dasyprocta leporina, an important seed disperser, in a Brazilian Atlantic Forest reserve. Tropical Conservation Science 7: 796-810.

Clark DA, Clark DB, Sandoval RM, Castro MVC. 1995. Edaphic and human effects on landscape-scale distributions of tropical rain forest palms. Ecology 76: 2581-2594.

Coimbra-Filho AF, Aldrighi AD. 1971. A restauração da fauna do Parque Nacional da Tijuca. Publicações Avulsas do Museu Nacional 57: 1-30. 
Coimbra-Filho AF, Aldrighi AD, Matins HF. 1973. Nova contribuição ao restabelecimento da fauna do Parque Nacional da Tijuca, GB, Brasil. Brasil Florestal 4: 7-25.

Condit R, Ashton PR, Baker P et al. 2000. Spatial patterns in the distribution of tropical tree species. Science 288: 1414-1418.

Connell JH. 1971. On the role of natural enemies in preventing competitive exclusion in some marine animals and in the rain forest trees. In: Boer PJ, Gradwell R. (eds.) Dynamics of populations. Wageningen, Centre for Agriculture Publications and Documentation. p. 298-310.

Cordeiro NJ, Howe HF. 2001. Low recruitment of trees dispersed by animals in African forest fragments. Conservation Biology 15: 1733-1741.

Costa RC, Santos, FAM. 2011. Padrões espaciais de Qualea grandiflora Mart. em fragmentos de cerrado no estado de São Paulo. Acta Botanica Brasilica 25: 215-222.

Cramer JM, Mesquita RCG, Bentos TV, Moser B, Williamson GB. 2007. Forest fragmentation reduces seed dispersal of Duckeodendron cestroides, a Central Amazon endemic. Biotropica 39: 709-718.

Dixon P. 2002. Ripley's $K$ function. In: El-Shaarawi AH, Piergorsch WW. (eds.) Encyclopedia of environmetrics. Chichester, John Wiley \& Sons. p. 1796-1803.

Donatti CI. 2004. Consequências da defaunação na dispersão e predação de sementes e no recrutamento de plântulas da palmeira brejaúva (Astrocaryum aculeatissimum) na Mata Atlântica. Msc Thesis, School of Agriculture Luiz de Queiroz, Brazil.

Donatti CI, Junior PRG, Galetti M. 2009. Seed dispersal and predation in the Atlantic rainforest palm Astrocaryum aculeatissimum across a gradient of seed disperser abundance. Ecological Research 24: 1187-1195.

Dracxler CM. 2012. Recrutamento de palmeiras em fragmentos de Mata Atlântica: entendendo as consequências das florestas vazias. $\mathrm{MsC}$ Thesis, Federal University of Rio de Janeiro, Brazil.

Dracxler CM, Pires AS, Fernandez FAS. 2011. Invertebrate seed predators are not all the same: seed predation by bruchine and scolytine beetles affects palm recruitment in different ways. Biotropica 43: 8-11.

Drumond JA. 1988. O jardim dentro da máquina: breve história ambiental da Floresta da Tijuca. Arquivos Históricos do Rio de Janeiro 1: 276-298.

Forget PM. 1991. Scatter-hoarding of Astrocaryum paramaca by Proechimys in French Guiana: comparison with Myoprocta exilis. Tropical Ecology 32: 155-167.

Forget PM, Munoz E, Leigh EGJR. 1994. Predation by rodents and bruchid beetles on seeds of Scheelea palms on Barro Colorado Island, Panama. Biotropica 26: 420-426.

Galetti M, Donatti CM, Pires AS, Junior PRG, Jordano P. 2006. Seed survival and dispersal of an endemic Atlantic forest palm: the combined effects of defaunation and forest fragmentation. Botanical Journal of the Linnean Society 151: 141-149.

Haase P. 1995. Spatial pattern analysis in ecology based on Ripley's K function: introduction and methods of edge correction. Journal of Vegetation Science 6: 575-582.

Hall P, Bawa K. 1993. Methods to assess the impact of extraction of non-timer tropical forest products on plant populations. Economic Botanic 47: 234-247.

Henderson A, Galeano G, Bernal R. 1995. Field Guide to the Palms of the Americas. New Jersey, Princeton University Press.

Hirsch BT, Kays R, Jansen PA. 2012. A telemetric thread tag for tracking seed dispersal by scatter-hoarding rodents. Plant Ecology 213: 933-943.

Hoch GA, Adler GH. 1997. Removal of black palm (Astrocaryum standleyanum) seeds by spiny rat (Proechimys semispinosus). Journal of Tropical Ecology 13: 51-58.

Howe HF. 1984. Implications of seed dispersal by animals for tropical reserve management. Biological Conservation 30: 261-281.

Howe HF, Smallwood J. 1982. Ecology of seed dispersal. Annual Review of Ecology and Systematics 13: 201-228.

ICMBio - Instituto Chico Mendes para a Conservação da Biodiversidade. 2008. Plano de Manejo: Parque Nacional da Tijuca. Brasília, ICMBio.

Janzen DH. 1970. Herbivores and the number of tree species in tropical forests. The American Naturalist 104: 501-528.

Jordano P. 2000. Fruits and frugivory. In: Fenner M. (ed.) Seeds: The Ecology of Regeneration in Plant Communities. Wallingford, CAB International.
Jorge MLSP, Howe HF. 2009. Can forest fragmentation disrupt a conditional mutualism? A case from central Amazon. Oecologia 161: 709-718.

Jorge MLSP, Peres CA. 2005. Population density and home range size of red-rumped agoutis (Dasyprocta leporina) within and outside a natural Brazil nut stand in southeastern Amazonia. Biotropica 37: 317-321.

Kuprewicz EK. 2013. Mammal abundances and seed traits control the seed dispersal and predation roles of terrestrial mammals in a Costa Rican Forest. Biotropica 45: 333-342.

Kurten EL. 2013. Cascading effects of contemporaneous defaunation on tropical forest communities. Biological Conservation 163: 22-32.

Lorenzi H, Sousa HM, Costa JTM, Cerqueira LSC, Ferreira E. 2004. Palmeiras Brasileiras: Nativas e Exóticas Cultivadas. São Paulo, Nova Odessa.

Perry GLW. 2004. SpPack: spatial point pattern analysis in Excel using Visual Basic for Applications (VBA). Environmental Modelling \& Software 19: 559-569.

Peters HA, Pauw A, Silman MR, Terborgh JW. 2004. Falling palm fronds structure Amazonian rainforest sapling communities. Proceedings of the Royal Society of London 271: 367-369.

Pires AS. 2006. Perda de Diversidade de Palmeiras em Fragmentos de Mata Atlântica: Padrões e Processos. PhD Thesis, Paulista State University, Brazil.

Pires AS, Galetti M. 2012. The agouti Dasyprocta leporina (Rodentia: Dasyproctidae) as seed disperser of the palm Astrocaryum aculeatissimum. Mastozoologia Neotropical 19: 147-153.

Portela RCQ. 2008. Ecologia populacional de três espécies de palmeiras em uma paisagem fragmentada no domínio da Mata Atlântica, RJ. PhD Thesis, Campinas State University, Brazil.

Portela RCQ, Bruna EM, Santos FAM. 2010. Demography of palm species in Brazil's Atlantic forest: a comparison of harvested and unharvested species using matrix models. Biodiversity and Conservation 19: 2389-2403.

Portela RCQ, Santos FAM. 2011. Caracterização dos estádios ontogenéticos de três espécies de palmeiras: uma proposta de padronização para estudos de dinâmica populacional. Revista Brasileira de Botânica 34: 523-535.

Potvin C, Cansari R, Hutton J, Caisamo I, Pacheco B. 2003. Preparation for propagation: understanding germination of giwa (Astrocaryum standleyanum), wagara (Sabal mauritiiformis), and eba (Socratea exorrhiza) for future cultivation. Biodiversity and Conservation 12: 2161-2171.

Ripley BD. 1977. Modelling spatial patterns. Journal of the Royal Statistic Society $39: 72-212$.

Ripley BD. 1979. Tests of 'randomness' for spatial point patterns. Journal of the Royal Statistic Society 41: 368-374.

Seidler TG, Plotkin JB. 2006. Seed dispersal and spatial pattern in tropical trees. Plos Biology 11: 2132-2137.

Silva MG, Tabarelli M. 2001. Seed dispersal, plant recruitment and spatial distribution of Bactris acanthocarpa Martius (Arecaceae) in a remnant of Atlantic forest in northeast Brazil. Acta Oecologica 22: 259-268.

Silvius K, Fragoso JV. 2003. Red-rumped agouti (Dasyprocta leporina) home range use in an Amazonian Forest: implications for the aggregated distribution of forest trees. Biotropica 35: 74-83.

Smythe N. 1989. Seed dispersal in the palm Astrocaryum standleyanum: evidence for dependence upon its seed dispersers. Biotropica 21: 50-56.

Svenning JC. 2001. On the role of microenvironmental heterogeneity in the ecology and diversification of Neotropical Rain-Forest palms (Arecaceae). The Botanical Review 67: 1-53.

Svenning JC, Harlev D, Sorense MM, Balslev H. 2009. Topographic and spatial controls of palm species distributions in a montane rain forest, southern Ecuador. Biodiversity and Conservation 18: 219-228.

Tabarelli M, Peres CA. 2002. Abiotic and vertebrate seed dispersal in the Brazilian Atlantic forest: implications for forest regeneration. Biological Conservation 106: 165-176.

Terborgh J, Nuñes-Iturri G, Pitman NCA, et al. 2008. Tree recruitment in an empty forest. Ecology 89: 1757-1768.

Vormisto J, Tuomisto H, Oksanen J. 2004. Palm distribution patterns in Amazonian rainforests: what is the role of topographic variation? Journal of Vegetation Science 15: 485-494.

Wang BC, Sork VL, Leong MT, Smith TB. 2007. Hunting of mammals reduces seed removal and dispersal of the afrotropical tree Antrocaryon klaineanum (Anacardiaceae). Biotropica 39: 340-347. 
Webber BL, Norton BA, Woodrow IE. 2010. Disturbance affects spatial patterning and stand structure of a tropical rainforest tree. Austral Ecology 35: 423-434.

Wright SJ. 2003. The myriad consequences of hunting for vertebrates and plants in tropical forests. Perspectives in Plant Ecology, Evolution and Systematics 6: 1-14.

Wright SJ, Duber HC. 2001. Poachers and fragmentation alter seed dispersal, seed survival, and seedling recruitment in the palm Attalea butyraceae, with implications for tropical tree diversity. Biotropica 33: 583-595.
Wright SJ, Zeballos H, Dominguez I, Gallardo MM, Moreno MC, Ibáñez R. 2000. Poachers alter mammal abundance, seed dispersal and seed predation in a Neotropical forest. Conservation Biology, 14: 227-239.

Zona S. 2006. Additions to a review of animal-mediated seed dispersal of palms. http://www.virtualherbarium.org/palms/psdispersal.html .

Zona S, Henderson A. 1989. A review of animal-mediated seed dispersal of palms. Selbyana 11: 6-21.

Zucaratto R. 2013. Os frutos que as cutias comiam: recrutamento da palmeira Astrocaryum aculeatissimum na ausência de seu principal dispersor de sementes. Msc Thesis, Federal Rural University of Rio de Janeiro, Brazil. 